\title{
Accidental poisoning by castor bean (Ricinus communis) cake in horses ${ }^{1}$
}

\author{
Daniele P. Montão ${ }^{2 *}$, Bruna T.S. Araújo ${ }^{2}$, Tiago F.S. Santos ${ }^{2}$, \\ Danielli B. Lima², Fábio T. Gonçalves², Marcos D. Duarte² ${ }^{2}$ Gabriela Riet-Correa ${ }^{2}$ \\ and Pedro S. Bezerra Júnior ${ }^{2}$
}

\begin{abstract}
Montão D.P., Araújo B.T.S., Santos T.F.S., Lima D.B., Gonçalves F.T., Duarte M.D., Riet-Correa G. \& Bezerra Júnior P.S. 2018. Accidental poisoning by castor bean (Ricinus communis) cake in horses. Pesquisa Veterinária Brasileira 38(10):1923-1928. Instituto de Medicina Veterinária, Universidade Federal do Pará, Campus Castanhal, Avenida Universitária s/n, Castanhal, PA 68746-360, Brazil. E-mail: pinamontao@hotmail.com

Ricinus communis is a shrub of the family Euphorbiaceae popularly known in Brazil as "mamona" or "carrapateira". It is an oleaginous plant whose seeds have been used mainly in biodiesel production. Plant seed oil can be extracted mechanically or using solvents, generating castor bean cake and castor bean meal as by-products, respectively. Accidental ingestion of these by-products can cause poisoning in animals and humans, characterized by digestive signs resulting from the presence of a toxalbumin called ricin. Seed toxicity varies among animal species; in horses, the lethal dose of seeds is $0.1 \mathrm{~g} / \mathrm{kg}$ of body weight. The literature presents plenty of studies addressing poisoning by R. communis in different animal species and in humans; however, reports are scarce and little information is available on the pathological aspects of poisoning regarding equines. Therefore, the present study aimed to describe the epidemiological, clinical and pathological aspects observed in an outbreak of accidental poisoning with castor bean cake in horses. The equines were supplemented with palm kernel (Elaeis guianeesis) cake; however, in the purchase of a new batch, there was an error in the order, and castor bean cake was requested instead. Four horses that received castor bean cake presented clinical signs indicative of colic, which started about 21 hours after administration. Three of these horses died, with clinical evolution from 2 to 4.5 hours; the other animal was treated with intravenous fluid and antibiotic therapy and non-steroidal anti-inflammatory drugs and recovered after five days. In the necropsy of two of these horses, the main lesions were found in the small intestine, where mucosae with pronounced redness and covered with a thin layer of yellow fibrous material were observed. In the intestinal lumen, there was a large amount of bloody liquid. The stomach was full, and dark lumps similar to crushed castor bean seeds were observed in the contents. The adrenal glands of both horses presented congestion and hemorrhage in the cortex. In microscopy, the main lesion was an acute, diffuse and accentuated fibrin-necrotic enteropathy affecting the jejunum. The diagnosis of castor bean cake poisoning was based on the circumstantial evidence of by-product consumption supported by clinical and pathological aspects. The results indicate that castor bean cake commercially available as fertilizer is extremely toxic when ingested, and there is a need for appropriate detoxification or labeling informing of its toxicity.
\end{abstract}

INDEX TERMS: Poisoning, castor bean cake, Ricinus communis, "carrapateira”, horses, colic, pathology, enteritis, diarrhea, toxicoses.

\footnotetext{
${ }^{1}$ Received on May 10, 2018.

Accepted for publication on May 24, 2018.

${ }^{2}$ Instituto de Medicina Veterinária, Universidade Federal do Pará, Campus Castanhal, Avenida Universitária s/n, Castanhal, PA 68746-360, Brazil.

*Corresponding author: pinamontao@hotmail.com
}

RESUMO.- [Intoxicação acidental por torta de mamona (Ricinus communis) em equinos.] Ricinus communis é um arbusto da família Euphorbiaceae conhecido popularmente como "mamona" ou "carrapateira". A planta é considerada 
oleaginosa e suas sementes têm sido utilizadas, principalmente, na produção de biodiesel. A extração do óleo pode ser mecânica ou com solventes, gerando, como subprodutos, a torta de mamona e a farinha de mamona, respectivamente. A ingestão acidental desses subprodutos pode causar intoxicação em animais e humanos, caracterizada por sinais digestivos devido a toxalbumina ricina. A toxidez das sementes varia entre as espécies animais, em equinos a dose letal de sementes é de $0,1 \mathrm{~g} / \mathrm{kg}$ de peso vivo. Há vasta literatura sobre a intoxicação por $R$. communis em diferentes espécies animais e humanos. Em relação aos equinos os relatos são escassos e com poucas informações sobre os aspectos patológicos da intoxicação. Assim, os objetivos do presente estudo foram descrever os aspectos epidemiológicos, clínicos e patológicos observados em um surto de intoxicação acidental por torta de mamona em equinos. Os equinos eram suplementados com torta de dendê (Elaeis guianeesis), no entanto, na compra de uma nova partida, houve um erro no pedido sendo solicitada torta de mamona. Os quatro equinos que receberam a torta de mamona apresentaram sinais clínicos indicativos de cólica, que iniciaram cerca de 21 horas após administração. Três destes morreram, com evolução clínica 2 a 4,5 horas, o outro animal foi tratado com fluidoterapia intravenosa, antibioticoterapia e anti-inflamatório não esteroidal, recuperando-se em 5 dias. Na necropsia de dois destes equinos, as principais lesões foram encontradas no intestino delgado, sendo observadas mucosas com avermelhamento acentuado e recobertas por fina camada de material amarelado fibrinoso. No lúmen intestinal, havia grande quantidade de líquido sanguinolento. 0 estômago estava repleto de grumos escuros semelhantes às sementes trituradas da mamona em meio ao conteúdo. As adrenais de ambos equinos apresentavam congestão e hemorragias corticais. Na microscopia, a principal lesão foi uma enteropatia fibrino-necrótica, aguda, difusa e acentuada, afetando com maior intensidade o jejuno. 0 diagnóstico de intoxicação por torta de mamona foi baseado na evidência circunstancial de consumo do subproduto, sendo corroborado pelos aspectos clínicos e patológicos. Os resultados indicam que a torta de mamona vendida para fertilização do solo é extremamente tóxica quando ingerida, havendo a necessidade de detoxicação ou rotulagem adequada informando sobre a sua toxicidade.

TERMOS DE INDEXAÇÃO: Intoxicação, torta de mamona, carrapateira, mamona, Ricinus communis, equinos, cólica, patologia, enterite, diarreia, toxicoses.

\section{INTRODUCTION}

Ricinus communis is an oleaginous plant of the family Euphorbiaceae (Borém 2009), popularly known in Brazil as "mamona" or "carrapateira", found throughout the Country (Lima et al. 2006, Tokarnia et al. 2012). R. communis seeds are rich in oil, known as castor oil (Ogunniyi 2006), which is widely used in biodiesel production because it presents high viscosity and density (Beltrão 2003). The three largest producers of $R$. communis seeds worldwide are India, China, and Brazil (Lima et al. 2006) respectively. In 2010, Brazil's production of these seeds was 93,025 tons (Barros \& Ramos 2017).

The main by-products generated from castor seed oil extraction are cake, meal, peel, and glycerol (Silva et al. 2010). Castor bean cake is obtained mechanically through seed pressing, and is used mainly as organic fertilizer (Patel et al. 2016).
Castor bean cake ingestion is extremely dangerous because it contains a toxin called ricin, which is present in large amounts in the endosperm of seeds, composing a major part of this material (Hong et al. 2011, Tokarnia et al. 2012).

Ricin can cause cell death by inhibition of protein synthesis (Doan 2004, Olsnes 2004), causing poisoning in several animal species, as well as in humans. Equines are especially sensitive to ricin, with a toxic dose of seeds of $0.1 \mathrm{~g} / \mathrm{kg}$ of body weight (Tokarnia et al. 2012). Clinical signs in the different species appear 6-30 h after ingestion of the seeds (Wooldridge 1918, Brito \& Tokarnia 1996, Fernandes et al. 2002, Aslani et al. 2007, Albuquerque et al. 2014), and clinical evolution to death varies from four to 56 hours (Brito \& Tokarnia 1996, Fernandes et al. 2002, Albuquerque et al. 2014).

Clinical signs of poisoning by $R$. communis seeds are associated with the gastrointestinal tract, with diarrhea, vomiting, and colic as the main signs described in horses (Wooldridge 1918). At necropsy, the major findings occur in the intestines (White 1918), with presence of bloody liquid particularly in the initial portion of the small bowel in horses (Wooldridge 1918) and other species, such as sheep, dogs, and cattle (Aslani et al. 2007, Hong et al. 2011, Albuquerque et al. 2014). In some cases, seed remnants are also observed in the contents of the digestive tract in horses and sheep (Wooldridge 1918, Albuquerque et al. 2014).

Although the specific scientific literature presents many studies addressing poisoning by $R$. communis in animals and humans, few reports have been found on poisoning in horses (White 1918, Wooldridge 1918, Fernandes et al. 2002, Tokarnia et al. 2012). In these few studies, the pathological aspects of poisoning in the equine species, especially regarding histopathology, are scarce or absent. Therefore, this study aimed to describe the epidemiological, clinical and pathological aspects observed in an outbreak of accidental poisoning by castor bean ( $R$. communis) cake in equines.

\section{MATERIALS AND METHODS}

Epidemiological and clinical data were obtained from the handlers and the owner of the horses on a visit to the property located in the municipality of Tracuateua, state of Pará, Brazil. During the visit, it was possible to clinically monitor and treat one of the affected horses and perform necropsy in two dead horses, from which fragments of several organs were collected and fixed in 10\% formalin for histopathological analysis.

Tissues were fixed in 10\% formalin for 48 hours, cleaved into smaller fragments, packed in plastic containers, identified, and processed using an automatic tissue processor (Leica TP 1020), in which they were dehydrated, diaphanized, and immersed in liquid paraffin. Subsequently, the tissues were embedded in paraffin and sliced into $5 \mu \mathrm{m}$-thick sections using a rotary microtome (Leica RM 2125 RT). The sections were placed on glass slides for staining with hematoxylin and eosin (HE) using a staining machine (SLEE MSM) and mounted with glass coverslip and Entellan ${ }^{\circledR}$.

\section{RESULTS}

According to reports of the owner and handlers, the equines in that property were supplemented with palm kernel cake. Nevertheless, in the purchase of a new batch, the orders were changed and castor bean cake was erroneously requested instead. It was then offered to four horses in a trough. Each 
horse received about $1 \mathrm{~kg}$ of a mixture containing castor bean cake and commercial feed. The intake varied from 30 to $70 \%$.

About 21 hours after administration, the horses began to show restlessness, and to lie down and get up frequently. Later, they began to roll and presented distended abdomen. Additionally, polydipsia, tenesmus, and anuria were reported, progressing to permanent decubitus and death. All four horses became ill and three of them died.

Clinical evolution to death varied from 2 to 4.5 hours. The surviving horse was treated with intravenous fluid and antibiotic therapy and non-steroidal anti-inflammatory drugs and recovered after five days.

In the two horses that underwent necropsy, the main macroscopic lesions were found in the jejunum and ileum. The mucosa of these intestine segments was reddened and covered with fibrous yellowish material. A large amount of bloody liquid was found in the lumen of the small intestine (Fig.1A) and dark lumps similar to crushed castor bean seeds were found in the lumen of the stomach (Fig.1B). Other lesions included erosion in the fundic region of the stomach (Fig.1C), congestion and hemorrhage in the adrenal cortex (Fig.1D), and pale areas in the cortex of the kidneys.

Histopathological examination of both equines showed major changes in the small bowel, more pronounced in the initial portion of the jejunum. There was acute, diffuse and marked, fibrin-necrotic enteropathy characterized by increased cytoplasmic eosinophilia and pyknosis (coagulative necrosis), denudation, and shortening of the villous enterocytes (Fig.2A). The lamina propria of the villi presented thrombosis in the capillaries, as well as fibrous material interspersed with cells with pyknosis (villous necrosis) (Fig.2B). There was also mild infiltration of mononuclear leukocytes into the lamina propria and submucosa, with rare eosinophils and mast cells. In the ileum, there was slight central-follicular rarefaction in the Peyer's plaques, with a small number of lymphocytes with pyknotic nuclei in the center of the follicles (Fig.2C) and

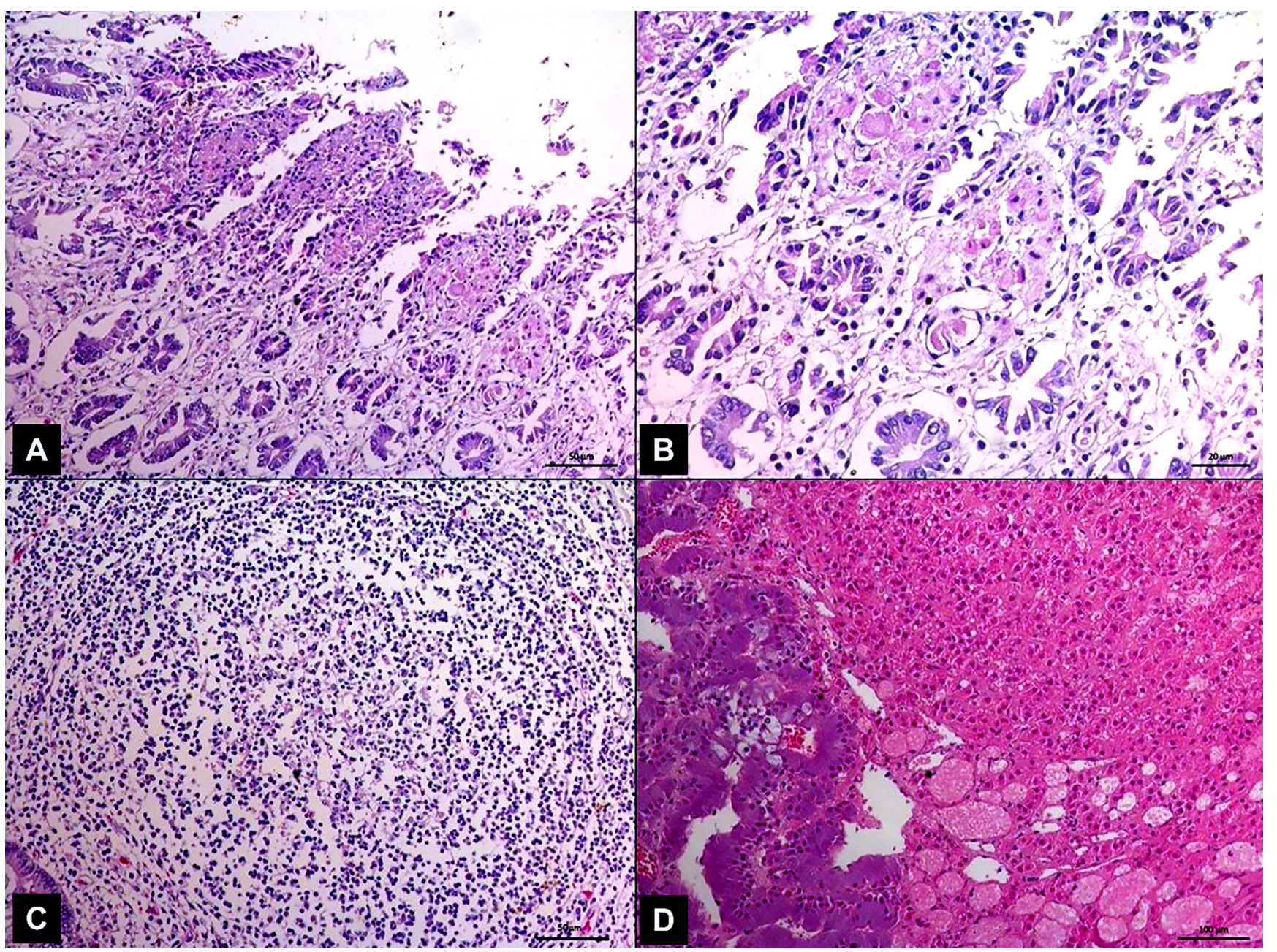

Fig.1. Accidental poisoning by castor bean (Ricinus communis) cake in horses. (A) Jejunum with necrosis and partial denudation of the villi and deposition of fibrous eosinophilic material on the lamina propria. HE, bar $=50 \mu \mathrm{m}$. (B) Jejunum (detail of the previous image) with necrotic enterocytes of the villi characterized by increased cytoplasmic eosinophilia and pyknotic nuclei (note contrast with enterocytes without changes in the crypts); in the lamina propria of the villi there are thrombi in the capillaries and mesenchymal stem cells with pyknotic nuclei interspersed with fibrous eosinophilic material (villus necrosis). HE, bar $=20 \mu \mathrm{m}$. (C) Ileum with slight central-follicular rarefaction and small number of lymphocytes with pyknotic nuclei. HE, bar $=50 \mu \mathrm{m}$. (D) Adrenal cortex with fasciculate and reticulate layer, congestion, necrosis, and marked diffuse hemorrhage. HE, bar $=100 \mu \mathrm{m}$. 


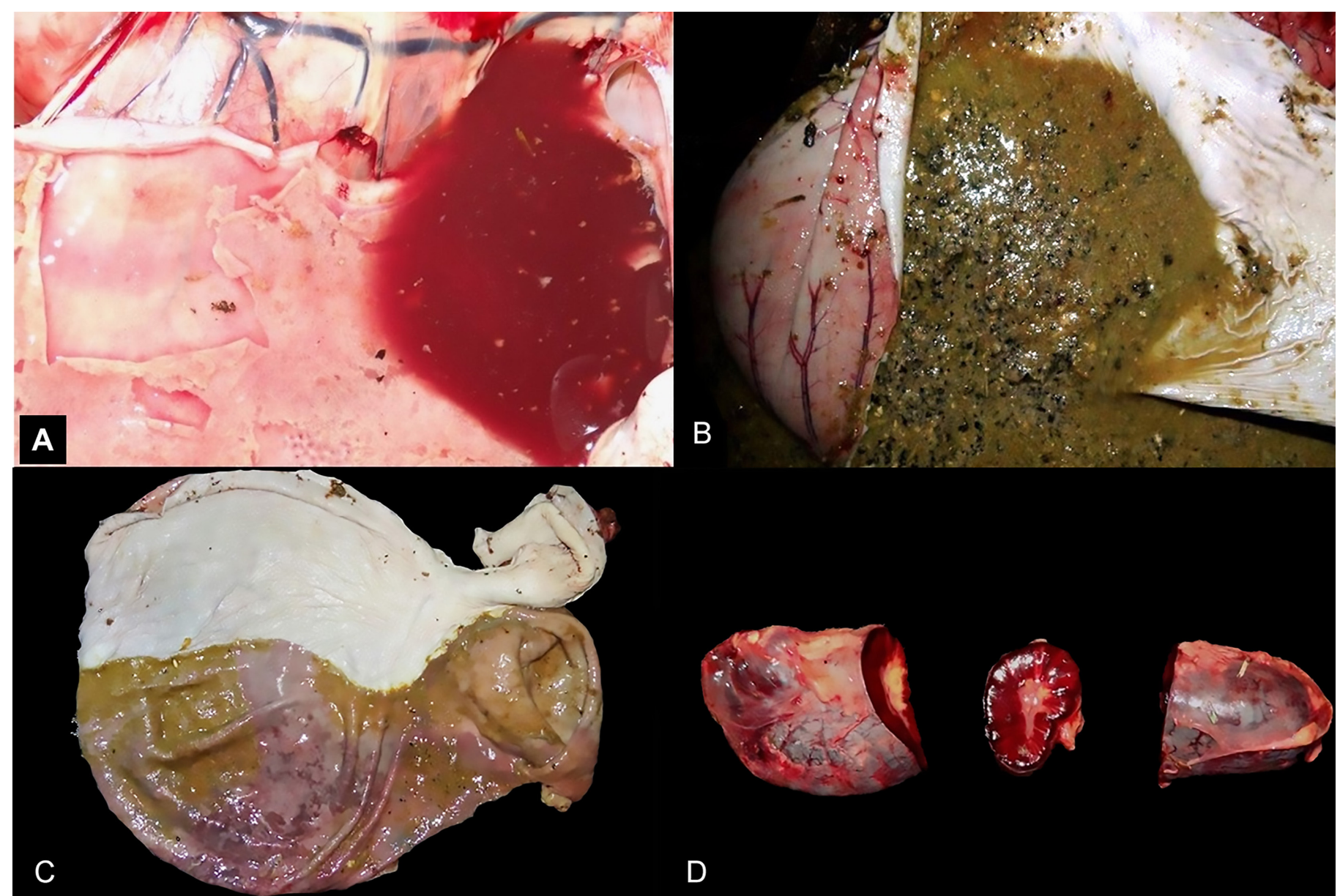

Fig.2. Accidental poisoning by castor bean (Ricinus communis) cake in horses. (A) Mucous membranes of the small bowel showing redness and covered with fibrous material, and bloody liquid content. (B) Stomach contents containing R. communis seed remnants. (C) Hemorrhage in the fundic region of the stomach. (D) Hemorrhage in the adrenal cortex.

a small number of macrophages laden with hemosiderin. The large intestine (cecum, right and left ventral colon, and left dorsal colon) presented dilated lymph vessels and mild mononuclear infiltrate with eosinophils in the lamina propria and submucosa.

The kidneys presented moderate congestion, mainly in the cortical and medullary junction, multifocal and discrete calcification of tubular epithelium, and rare macrophages laden with hemosiderin in the glomerular tufts. In the liver, a small number of macrophages laden with hemosiderin were found in the portal space and rare Kupffer cells with hemosiderin were observed. Extensive areas of congestion, hemorrhage, and necrosis, mainly in the fasciculate and reticulated layers of the cortex, were observed in the adrenal glands (Fig.2D). In some areas, there were cholesterol clefts amid necrosis and hemorrhage.

\section{DISCUSSION}

The diagnosis of poisoning with castor bean cake in the horses of the present study was based on the circumstantial evidence of ingestion of this by-product, and was corroborated by epidemiological, macroscopic and histopathological findings similar to those described in previous studies conducted with equines (White 1918, Wooldridge 1918, Fernandes et al. 2002) and other animal species (Aslani et al. 2007, Hong et al. 2011, Tokarnia et al. 2012, Albuquerque et al. 2014).

Wooldridge (1918) reported that of 19 horses fed a mixture of oats and hay containing castor bean seeds, 16 (84.21\%) sickened and three of these (18.75\%) died. White (1918) described cases in equines of two farms of the same owner. The horses that were fed a mixture of corn and castor bean seeds presented with $100 \%$ morbidity and $16.66 \%$ lethality. The present study observed 100\% morbidity and 75\% mortality. The higher lethality verified in the present outbreak is probably due to the type of product associated with this case. Other studies addressing equine poisoning found in the literature are associated with ingestion of castor bean seeds, whereas the horses of the present report were poisoned by castor bean cake. As this by-product is obtained after pressing of the seeds to remove oil, ricin concentrations tend to remain higher in the residue, because this toxin is localized only in the endosperm of the seeds, and not in the oil (Pita et al. 2004).

The first clinical signs shown by the horses in this study were observed about 21 hours after provision with castor bean cake. This time is in agreement with that described for equines (6-30 h after ingestion of the seeds) (Wooldridge 1918, 
Fernandes et al. 2002), bovines (Albuquerque et al. 2014), sheep (Aslani et al. 2007), and rabbits (Brito \& Tokarnia 1996). In contrast, the clinical evolution to death in the horses in this study ranged from 2 to 4.5 hours, considerably shorter than that observed by Wooldridge (1918), who reported a 2-day evolution, and by White (1918), who described evolution of about 24 hours. Clinical evolution to death of 48-72 hours was observed in cattle (Albuquerque et al. 2014). The shorter clinical evolution observed in this report may be associated with the greater toxicity of castor bean cake compared with that of seeds. Castor bean cake is prepared after extraction of the oil, and only the endosperm of the seeds remains, which contains large amounts of ricin, thus concentrating the toxin (Hong et al. 2011, Tokarnia et al. 2012).

The horses of the present survey presented mainly signs of cramping abdominal pain, similar to those described in equines in previous studies (Wooldridge 1918, Fernandes et al. 2002). Diarrhea, often described in poisoning by castor seeds in other species such as sheep and dogs (Aslani et al. 2007, Hong et al. 2011), was not observed in the horses of the present outbreak. It is possible that superacute clinical evolution has caused the death of the animals before development of diarrhea. The horses also showed signs of weakness, inappetence, depression, and dehydration, with their consequences (anuria and polydipsia). Similar signs have been reported in poisoning by $R$. communis in other animal species, such as sheep (Aslani et al. 2007), dogs (Hong et al. 2011), and bovines (Albuquerque et al. 2014),

Presence of castor seed remnants observed in the stomach contents of the equines of this study has also been previously described in research conducted with horses (Wooldridge 1918) and bovines (Albuquerque et al. 2014).

Fibrin-hemorrhagic lesions observed at necropsy in the jejunum and ileum of the horses in this study were similar to those described in poisoning by $R$. communis in equines in another survey (Wooldridge 1918), as well as in research on other animal species (Worbs et al. 2011).

Lesions found in histopathology of the horses of the present outbreak are similar to those observed in studies addressing other intoxicated species, such as bovines (Albuquerque et al. 2014), sheep (Aslani et al. 2007), rabbits (Brito \& Tokarnia 1996), and dogs (Hong et al. 2011).

Hong et al. (2011) described, at microscopy, that there were marked congestion in the submucosa and muscular layers and degeneration of the intestinal epithelial cells in cases of poisoning in dogs. However, in the present study, the lesion was classified as fibrin-necrotic enteropathy due to observation of coagulation necrosis of enterocytes as well as fibrin deposition on the lamina propria of the villi and on the denuded villi.

In this report, it was evidenced that the lesions affected the jejunum villi more strongly. These results corroborate the findings by Aslani et al. (2007) in their report on poisoning in sheep. In this study, light mononuclear infiltrate with eosinophils was observed on the lamina propria and submucosa of all analyzed portions of the small and large intestines in both necropsied equines. These data coincide with those reported by Aslani et al. (2007) in sheep and by Albuquerque et al. (2014) in cattle. However, interpretation of this infiltrate is complex, because this transit of leukocytes has also been interpreted as a physiological event in the intestinal mucosa (Brown et al. 2007).

Hong et al. (2011) found vacuolar degeneration and necrosis in renal tubular epithelium in dogs and Aslani et al. (2007) described hyperemia, hemorrhage, and necrosis in the kidneys of sheep. However, congestion was observed in the horses of the present study, with no degeneration and tubular necrosis.

Congestion and cortical hemorrhage were observed in the adrenal glands of the equines of the present study. These changes were considered similar to lesions indicative of circulatory shock (Cheville 1999). The extensive lesions observed in the jejunum and ileum of the horses submitted to necropsy were considered sufficient to trigger a hypovolemic shock that could explain the lesions in the adrenal glands. Response to treatment, based on intravenous fluid and antibiotic therapy and non-steroidal anti-inflammatory drugs, of the surviving equine reinforces the idea of hypovolemic shock as the main cause of death of the untreated horses.

Different causes of enteritis in horses should be considered in the differential diagnosis of poisoning by Ricinus communis, such as salmonellosis, clostridiosis by Clostridium difficile, and equine monocytic ehrlichiosis (McGavin \& Zachary 2013). In the present case, the circumstantial evidence of castor bean cake ingestion, the clinical signs and compatible lesions, and the presence of the by-product in the stomach contents were decisive for the diagnosis.

\section{CONCLUSIONS}

Castor bean (Ricinus communis) cake is available on the market as a fertilizer in a non-detoxified form, which is toxic to horses when ingested. Therefore is need for detoxification or information to consumers and/or labeling indication concerning the risk of using this by-product in animal feed.

The outbreak reported herein demonstrates that poisoning by castor bean cake in horses can present a high rate of morbidity $(100 \%)$ and lethality $(75 \%)$, with superacute evolution.

The diagnosis of this report was based on evidence of consumption of the by-product and clinical-pathological condition, characterized by fibrin-necrotic enteropathy, more intense in the initial portion of the small intestine (jejunum).

Acknowledgements.- The authors are grateful to Tomaz Pina Maia, DVM, for his support and opportunity to develop this study, to the Coordination for the Improvement of Higher Education Personnel (CAPES), for the grant provided, and to the Pro-Rectory of Research and Graduate Studies (PROPESP) of the Federal University of Para (UFPA), for the assistance with the publication of this article through the Program of Support to Qualified Publication (PAPQ).

\section{REFERENCES}

Albuquerque S.S.C., Rocha B.P., Albuquerque R.F., Oliveira J.S., Medeiros R.M.T., Riet-Correa F., Evêncio-Neto J. \& Mendonça F.S. 2014. Spontaneous poisoning by Ricinus communis (Euphorbiaceae) in cattle. Pesq. Vet. Bras. 34(9):827-831. <http://dx.doi.org/10.1590/S0100-736X2014000900004>

Aslani M.R., Maleki M., Mohri M., Sharifi K., Najjar-Nezhad V. \& Afshari E. 2007. Castor bean (Ricinus communis) toxicosis in a sheep flock. Toxicon 49(3):400-406. <http://dx.doi.org/10.1016/j.toxicon.2006.10.010> <PMid:17157890> 
Barros M.A.L. \& Ramos G.A. 2017. Agencia Embrapa de Informação Tecnológica Available at <http://www.agencia.cnptia.embrapa.br/gestor/mamona/ arvore/CONT000h4pitb4s02wx7ha0awymtyiscijnl.html> Access on Oct. 22,2017

Beltrão N.E.M. 2003. Informações sobre o biodiesel, em especial feito com o óleo de mamona. Embrapa Algodão, Campina Grande. Comunicado Técnico, 177.

Borém A. 2009. Hibridação Artificial em Plantas. Vol.2. Editora UFV, Viçosa, MG, p.391-392.

Brito M.F. \& Tokarnia C.H. 1996. Intoxicação experimental pelas sementes trituradas de Ricinus communis (Euphorbiaceae) em coelhos. Pesq. Vet. Bras. 17(1):1-7. <http://dx.doi.org/10.1590/S0100-736X1997000100001>

Brown C.C., Baker D.C. \& Barker K. 2007. Alimentary system, p.69-127. In: Jubb K.V.F., Kennedy P.C. \& Palmer N. (Eds), Pathology of Domestic Animals. 2vol. Academic Press, Cambridge, Massachusetts.

Cheville N.F. 1999. Introduction to Veterinary Pathology. Vol.2. Wiley, Oxford, p.352.

Doan L.G. 2004. Ricin: mechanism of toxicity, clinical manifestations, and vaccine development. J. Toxicol., Clin. Toxicol. 42(2):201-208. <http:// dx.doi.org/10.1081/CLT-120030945><PMid:15214627>

Fernandes W.R., Baccarin R. Y. A. \& Michima L.E.S. 2002. Intoxicação em equino por Ricinus communis: relato de caso. Revta Bras. Saúde Prod. Anim., Salvador, 3(1):26-31.

Hong I.H., Kwon T.E., Lee S.K., Park J.K., Ki M.R., Park S.I. \& Jeong K.S. 2011. Fetal death of dogs after the ingestion of a soil conditioner. Exp. Toxicol. Pathol. 63(1/2):113-117.<http://dx.doi.org/10.1016/j.etp.2009.10.004> <PMid:19932603>

Lima R.S., Severino L.S., Silva M.I.L., Vale L.S. \& Beltrão N.E.M. 2006. Volume de recipientes e composição de substratos para Produção de mudas de mamoneira. Ciênc. Agrotec. Lavras 30(3):480-486.
McGavin M.D. \& Zachary J.F. 2013. Bases da Patologia Veterinária. Vol.2. Elsevier, Rio de Janeiro, p.378-384.

Ogunniyi D.S. 2006. Castor oil: a vital industrial raw material. Bioresour. Technol. 97(9):1086-1091. <http://dx.doi.org/10.1016/j.biortech.2005.03.028> <PMid:15919203>

Olsnes S. 2004. The history of ricin, abrin and related toxins. Toxicon 44(4):361-370. <http://dx.doi.org/10.1016/j.toxicon.2004.05.003> $<$ PMid:15302520>

Patel V.R., Dumancas G.G., Viswanath L.C.K., Maples R. \& Subong B.J.J. 2016. Castor oil: properties, uses, and optimization of processing parameters in commercial production. Lipid Insights 9:1-12. < http://dx.doi.org/10.4137/ LPI.S40233> <PMid:27656091>

Pita R., Anadón A. \& Martínez M. 2004. Ricina: una fitotoxina de uso potencial como arma. Revta Toxicol. 2:51-56.

Silva M.S., Macedo L.C., Santos J.A.B., Moreira J.J.S., Narain N. \& Silva G.F. 2010. Aproveitamento de co-produtos da cadeia produtiva do biodiesel de mamona. Exacta 8(3):279-288.

Tokarnia C.H., Brito M.F., Barbosa J.D., Peixoto P.V. \& Döbereiner J. 2012. Plantas Tóxicas do Brasil. 2ª ed. Editora Helianthus, Rio de Janeiro, p.119-124.

White M.E. 1918. Poisoning of horses with castor seeds. J. Comp. Pathol. Ther. 31:98-100. <http://dx.doi.org/10.1016/S0368-1742(18)80013-3>

Wooldridge G.H. 1918. Castor seed (Ricinus communis) poisoning in horses. J. Comp. Pathol. Ther. 31:94-98. <http://dx.doi.org/10.1016/S03681742(18)80012-1>

Worbs S., Köhler K., Pauly D., Avondet M.A., Schaer M., Dorner M.B. \& Dorner B.G. 2011. Ricinus communis intoxications in human and veterinary medicine-a summary of real cases. Toxins 3(10):1332-1372. <http:// dx.doi.org/10.3390/toxins3101332> <PMid:22069699> 